\title{
Agency theory and foreclosure sales of properties
}

\author{
K W Chau ${ }^{1}$ and R C K Ng \\ Department of Real Estate and Construction, The University of Hong Kong
}

\begin{abstract}
This study analyze s the effect of foreclosure status on residential property price using Hong Kong data. Results of previous studies on the effect of foreclosure status on property price have been mixed. Some suggested that foreclosed properties are sold at a discount, while others provided contrary evidence. In this study, we propose that agency issues, which were ignored in previous studies, have an important role to play in determining the prices of foreclosed properties under different market conditions. When the market is booming, the mortgage loan on a property is likely to be lower than its market value. The bank's objective is to sell the property as quickly as possible to recover the loan. The tradeoff between time-on-the-market and transaction price implies that foreclosed properties are sold at a discount to market prices. On the other hand, during market downturns, the mortgage loan is likely to be higher than the market value. The banks will have less incentive to trade time-on-the-market for price, and foreclosed properties are less likely to be sold at a discoulnt, and thus add bad debts into their books. Empirical results from Hong Kong suggest that that foreclosed properties are sold at a $10 \%$ discount in an up market, but are sold at no discount in a down market. The results are consistent with our prediction.
\end{abstract}

\section{Keywords}

Agency theory, foreclosure, hedonic price model, Hong Kong, residential properties

\footnotetext{
${ }^{1}$ Please comments to

K W Chau

Department of Real Estate and Construction

The University of Hong Kong

PokfulamRoad, Hong Kong

E-mail: hrrbckw@hku.hk

Fax: 85225599457
} 


\section{I ntroduction}

Home purchases are usually financed by mortgage loans. When the mortgage payment is due, there are three explicit options embedded in mortgage contracts - pay the mortgage payment, prepay the loan, and default on the payment. Normally, the mortgagor will pay the mortgage payment. However, if he is not able to do so, he can either prepay the mortgage sum by selling the properties or he can default on the payment and wait for a foreclosure order.

In order to let the mortgagor make a better decision among the three options, information on the costs of the options must be obtained. The a vailability of information can increase the transparency of the market and increase market efficiency. Ambrose and Buttimer (2000) show that credit reputation, which affects future credit opportunities, is the cost of the default and foreclosure option. Therefore, any discount in the foreclosure sale price to market value can also be viewed as one of the relevant costs associated with the default option. On the other hand, competition among buyers in the real estate market will tend to eliminate any discount.

Whether foreclose properties are sold a discount is an area of study that interests not only academics, but valuers, real estate investors, financial intermediaries, and policymakers. Results from previous empirical studies, mainly based on US data, have been mixed, and there has been a lack of explanation to reconcile these seemingly inconsistent observations from different studies. This study attempts to fill this gap.

The sale of foreclosed properties is different from ordinary sales in the form of contracts, property condition, and the nature of sellers. In a foreclosure sale, the banks (or mortgagees) act as the agents of the property owners (or the mortgagors). Agency issues arise as the motivations of the banks may be different under different loan-tovalue ratios, as the market value of a property changes with market conditions. We use the Agency Theory to explain how the price of a foreclosed property may deviate from its market value under different market conditions.

This paper is organized as follows. The next section presents a brief review of previous studies on foreclosure sales. We will then present the principle-agent problem in a foreclosure sale and deduceempirical implications from agency theory. The sections that follow describe the design and data of empirical tests. The empirical results are then presented and discussed. The last section is the conclusion.

\section{Brief literature review}

Shilling, Benjamin, and Sirmans (1990) proposed a model to estimate net realizable value for distressed real estate from market value. They concluded that there are two reasons for the difference between market value and net realizable value for distressed real estate. One is the liquidating discount, or the amount the lender is willing to give up in order to sell the property quickly. Another is the adjustment for costs associated with ownership, development, operations, and the sale of the property. 
Forgey, Rutherford, and Vanbuskirk (1994) examined a data set consisting of 2,482 single-family residential property sales obtained from the Arlington, Texa s multiple listing service files sold over the period J uly 1991 through January 1993. Foreclosure sales constituted $11.28 \%$ of the sample. The authors employed a log-linear regression model and found a $23 \%$ discount in price for the foreclosed property sales.

Hardin \& Wolverton (1996) extended the result of Forgey, et al. to include income producing properties. They concluded that the sellers of foreclosed properties did not fit the market value definition of a typically motivated seller, and the sellers had a rationale for accepting reduced market prices in exchange for quick sales.

Carroll, Clauretie, \& Neill (1997) questioned the results of Forgey, et al.. They argued that the observed discount is attributable to the condition of the foreclosed properties and their neighborhoods. They showed that the foreclosure discounts we re very small (between $0.17 \%$ and $2.58 \%$ ) and no longer statistically significant after being adjusted for different property and neighborhood conditions.

Pennington-Cross (2006) found that foreclosed properties appreciate at a slowerthan average rate in same metropolitan areas. His results showed that foreclosed properties appreciated, on average, 22 percent slower than the area average appreciation rate. The magnitude of the difference of the foreclosure discount was sensitive to housing conditions, legal constraints, and loan characteristics. He also found that the longer a lender owned a piece property (real estate owned property) after default, the larger the foreclosure discount (actual minus area wide appreciation) would be.

Based on a set of transaction records in Singapore, Ong et. al. (2006) show that properties that are purchased at a premium paid have a higher probability of foreclosure, ceteris paribus. This suggest that market price of property may not always be rational.

Ong et. al. (2008) found that differences in seller response to market expectations and equity losses exist across foreclosure and non foreclosure transactions. Their results suggest that lenders may not act in the best interest of the foreclosed owners to get the best price possible.

The above studies showed that the effect of foreclosure status on property price is likely to be affected by many factors. With the exception of the last, none of these studies, however, examined the influence of the potential divergence in the interests between the mortgagee and mortgagor in a foreclosed sale. Based on Agency Theory, we propose that such a divergence, which is conditional on the loan-to-value ratio of a foreclosed property and changes with market conditions, has an impact of the sales price of foreclosed properties.

\section{The Principle-Agent problem in foreclosure sales}

The principle-agent problem, or agency issue, as the name implies, refers to the problems arising from the conflicting interests between the principle and the agent who is making decisions on beha If of the principle. Agency theory was developed to explain how people behave when there are principle -agent problems. It had the most success in dealing with strategies for improving efficiency (DeGeorge 1992). The relationship between lenders (banks) and mortgagors in foreclosure sales is a typical principle-agent 
relationship. Thus, agency theory is also relevant for explaining the effect of the foreclosure status of a property on its selling price.

Mitnick (1992) suggested that the major insight of agency theory is that control loss is inevitable in agent-principal relationships. The agent and principal are supposed to have different objectives, so the principal must expend resources both in trying to instruct the agent on what to do and monitoring and policing the agent's behavior.

In the case of a foreclosure sale, the bank (principle) acts on behalf of the property owner (agent). The major principle-agent problem (or agency issue) is that the bank's interest is to sell the property as quickly as possible and recover the loan, while the property owner would like to sell at the highest price possible. Previous studies suggested that there is a tradeoff between a property's time on the market and its selling price. That is, the longer the seller can wait, the more likely that $s / h e$ can find a buyer whose taste matches the characteristics of the property, and is thus willing to pay a higher price. This search model is consistent with the higher information costs in the real estate market. When the size of the mortgage loan is smaller than the market value, the bank has an incentive to sell as quickly as possible as long as the realized price can cover the loan. As future price is uncertain, risk-averse lenders will minimize the search time at the expense of a lower selling price. Therefore, a lot of foreclosure properties are sold by auction or tender rather than through negotiation.

The story is different when the mortgage loan is smaller than the market value of the property. Under this scenario, bad debt may arise if the borrower cannot pay the difference between the mortgage loan and the net proceeds from the sale of the property (in Hong Kong, most mortgage contracts stipulate that the mortgagor is personally liable for mortgage debt). Under this scenario, the banks have an incentive to wait for the possibility of selling at higher prices. In addition, a foreclosure sale may immediately lead to an increase in bad debt in the lender's financial statement, which could have an adverse effect on the share price of a company or the performance of its management. The agency issue may therefore be smaller, as the interests of the mortgagee are more in line with those of the mortgagor. The loan-to-value ratio increase of a property increases as market price declines. The implication is that the discount of the foreclosed sales price to the market price is likely to be smaller (or even disappear) in a down-market.

\section{Empirical tests}

We tested the implications of our agency hypothesis by estimating the following hedonic price model using transaction data from Hong Kong:

$$
\begin{gathered}
\ln (\mathrm{RP})=\mathrm{a}_{0}+\mathrm{a}_{1} \mathrm{AGE}+\mathrm{a}_{2} \mathrm{AGE}^{2}+\mathrm{a}_{3} \mathrm{FL}+\mathrm{a}_{4} \mathrm{FL}^{2}+\mathrm{a}_{5} \mathrm{GFA}+\mathrm{a}_{6} \mathrm{GFA}^{2}+\mathrm{a}_{7} \mathrm{SV}+ \\
\mathrm{a}_{8} \mathrm{FORE}+\mathrm{a}_{9} \mathrm{TD}^{*} \mathrm{FORE}+\epsilon
\end{gathered}
$$

where $\ln (\mathrm{RP})$ is the natural logarithm of transaction price in real terms, AGE is the Age of the Property, GFA is the Gross Floor Area, FL is the Floor Level, SV is the sea view dummy, which equals 1 if the property has a sea viewand zerootherwise; FORE is the foreclosure status dummy, which equals 1 for foreclosed properties and zero otherwise, 
TD is the market condition dummy, which equals one if the property is sold in an up market and zero otherwise, and $\in$ is the error term.

$A G E^{2}, \mathrm{FL}^{2}$, and $\mathrm{GFA}^{2}$ were included to test the linearity of the effects of Age, Floor Level, and Gross Floor Area. They could be increasing/decreasing at an increasing rate (if square term is $+v e$ ) or increasing/decreasing at a decreasing rate (if square term is ve). The expected signs of the variables are summarized below in Table 1.

Table 1: Expected signs of the coefficients of the variables in the hedonic price model:

\begin{tabular}{|c|c|}
\hline Variable & Expected Sign \\
\hline AGE & -ve \\
\hline $\mathrm{AGE}^{2}$ & $?$ \\
\hline $\mathrm{FL}$ & +ve \\
\hline $\mathrm{FL}^{2}$ & $?$ \\
\hline GFA & +ve \\
\hline $\mathrm{GFA}^{2}$ & $?$ \\
\hline SV & + ve \\
\hline FORE & -ve \\
\hline FORE ${ }^{*} \mathrm{TD}$ & -ve \\
\hline
\end{tabular}

\section{Data}

Transaction records of housing units in Tai Koo Shing over the period July 1996 - March 2000 were collected for the empirical tests. Tai Koo Shing is one of the largest housing estate s in Hong Kong, consisting of 61 buildings and more than 10,000 housing units. The housing units are actively transacted, and are relatively homogeneous and therefore reduce the number of coefficients that need to be estimated.

The period of observation included phases of a clear up trend (J uly 1996 - September 1997) and down trend (January 1998- March 2000). To make the results more robust and reduce the noise in the data, we only included data during clear up and down markets. This approach was similar to that of Chau and $\mathrm{Ng}$ (1998) and Chau, Ma, and Ho (2000).

The transaction records, which include addresses, prices, completion dates, dates of sale, and the identities of the buyers and sellers, are available from the Land Registry of the Hong Kong Government. The price indices for deflating the transaction prices are the official residential price indices constructed by the government's Rating and Valuation Department. A more detailed discussion of the indices can be found in Chau, Wong, Yiu, and Leung (2005). The descriptive statistics of the quantitative variables are show in Table 2 . 
Table 2: Descriptive statistics of the variables used in the hedonic price model

\begin{tabular}{|lrrrr|}
\hline Variable & Maximum & Minimum & Mean & $\begin{array}{r}\text { Standard } \\
\text { Deviation }\end{array}$ \\
\hline Real Price & 127,158 & 12,366 & 42,722 & 12546.85 \\
AGE (year) & 23.03 & 9.09 & 15.265 & 3.234 \\
FL & 30 & 1 & 14.841 & 7.612 \\
GFA (sq ft) & 2,012 & 338 & 820.7 & 179.443 \\
\hline
\end{tabular}

\section{Empirical Results}

The results of estimating Equation (1) are shown in Table 3. The high value of the adjusted R-squared was a result of the homogeneous nature of the units. Most of the coefficients of the independent variables were of the expected sign and statistically significant at the $5 \%$ level. The coefficient of FORE was not statistically significant, indicating that foreclosed properties did not sell at a discount during the market downturn $(T D=0)$. However, the coefficient of TD*FORE was negative and significant at the $1 \%$ level, meaning that the foreclosed properties showed a discount from the market price. The discount, on average, was as large as $10 \%$. These results are consistent with our prediction-based agency theory.

Table 3 Results of estimating Equation (1)

\begin{tabular}{|l|c|c|c|}
\hline \multicolumn{3}{|c|}{ Dependent Variable: Logarithm of Real transaction prices (In(RP)) } \\
\hline Variable & Coefficient & Std. Error & t-statistic \\
\hline Constant & 9.3427 & 0.04167 & $224.2199^{*}$ \\
AGE & -0.0463 & 0.004022 & $-11.50136^{*}$ \\
FL & 0.0009 & 0.00013 & $6.8804^{*}$ \\
FI & 0.0142 & 0.000822 & $17.3028^{*}$ \\
GFA & -0.0003 & $2.63 \times 10^{-5}$ & $-12.6419^{*}$ \\
GFA & 0.0026 & $6.01 \times 10^{-5}$ & $44.0207^{*}$ \\
SV & $-7.42 \times 10^{-7}$ & $3.28 \times 10^{-8}$ & $-22.6329^{*}$ \\
FORE & 0.0184 & 0.00504 & $3.6522^{*}$ \\
TD*FORE & 0.0123 & 0.014785 & 0.8335 \\
R & -0.1011 & 0.03476 & $-2.9095^{*}$ \\
Adjusted R & 0.8959 & & \\
F-statistic & 0.8961 & & \\
No. of Observations & 4057.269 & & \\
\hline
\end{tabular}

*The coefficient is statistically significant at the $5 \%$ level 
White's (1980) test for heteroscedasticity suggested that the variance of the error term is not constant for ( $p$-value $<0.1 \%$ ). We therefore used White's method for correcting heteroscedasticity. The results are presented in Table 4. They are similar except that the coefficient of TD*FORE is slightly less significant, but still significant, at the $5 \%$ level.

\section{Conclusion}

We have shown that the effects of foreclosure status on residential property price under different market conditions are different. As the agents of the owners in the sale of foreclosed properties, the interests of banks may not be in line with that of the owners. In an upturn market, in which the mortgage d loan is likely to be higher than the market value, banks would like to reduce their risk of future changes in market value by selling the properties as soon as possible. From the viewpoints of a bank, a discount is not a cost to it, as the proceeds from selling properties are higher than the loans. However, in a downturn market, the mortgage loan is likely to be higher than the market price. Banks would have an incentive to maximize their selling prices so as to reduce their potential losses. The difference in the motivation of the sellers results in different effects of foreclosure status on property prices under different market conditions.

Our empirical results are consistent with this analysis. The results show that foreclosed properties are not sold at a discount in downturn ma rkets, but at significant (approximately a $10 \%$ in our sample) discount to market price in upturn markets. We believe this should partly explain the mixed empirical results of the previous studies.

Table 4: Least squares estimates of Equation (1) after correcting for heteroscedasticity.

\begin{tabular}{|c|c|c|c|}
\hline \multicolumn{4}{|c|}{ Dependent Variable: Logarithm of Real transaction prices (In(RP)) } \\
\hline Variable & Coefficient & Std. Error & t-statistic \\
\hline Constant & 9 & 0 & $113.9934^{*}$ \\
\hline AGE & -0.0463 & 0.003944 & $-11.7281^{*}$ \\
\hline $\mathrm{AGE}^{2}$ & 0.0009 & 0.000127 & $7.0614^{*}$ \\
\hline $\mathrm{FL}$ & 0 & 0.000873 & $16.3084 *$ \\
\hline $\mathrm{Fl}^{2}$ & 0 & $2.79 \times 10^{-5}$ & $-11.9187^{*}$ \\
\hline GFA & 0.0026 & 0.000159 & $16.6610^{*}$ \\
\hline $\mathrm{GFA}^{2}$ & $-7.42 \times 10^{-7}$ & $9.25 \times 10^{-8}$ & $-8.0185^{*}$ \\
\hline sv & 0 & 0.008012 & $2.2973^{*}$ \\
\hline FORE & 0 & 0 & 1 \\
\hline TD*FORE & -0.1011 & 0.042405 & $-2.3849 *$ \\
\hline$R^{2}$ & 0.896119 & & \\
\hline Adjusted $R^{2}$ & 1 & & \\
\hline F-statistic & 4,057 & & \\
\hline No. of Observations & 4243 & & \\
\hline
\end{tabular}

*The coefficient is statistically significant at $5 \%$ level 


\section{References}

Ambrose, B.W. and Buttimer, R.J . (2000) Embedded Options in the Mortgage Contract, Journal of Real Estate Finance and Economics, 21(2), 95-111.

Chau, K.W. \& Ng, F.F. (1998) The effects of improvement in public transportation capacity on residential price gradient in Hong Kong, Journal of Property Valuation and Investment, 16(4), 397-410.

Chau, K.W., Ma, S.M. and Ho, D.C.W. (2000) "The pricing of 'luckiness' in the apartment market" (2000), J ournal of Real Estate Literature, 9 (1), 31-40

Correll, M.R., Lillydahl, J.H. \& Singell, L.D. (1978) The Effects of Greenbelts on Residential Property Values: Some Findings on the Political Economy of Open Space, Land Economics , 54(2), 207-216.

DeGeorge, R.T.(1992) Agency Theory and the Ethics of Agency in, Bowie, N.E. \& Freeman, R.E. (ed.), Ethics and Agency Theory, Oxford University Press, New York, 5972.

Forgey, F.A., Rutherford, R.C. \& van Buskirk, M.L. (1994) Effect of Foreclosure Status on Residential Selling Price, The J ournal of Real Estate Research , 9(3), 313-18.

Hardin, W.G. \& Wolverton, M.L. (1996) The Relationship Between Foreclosure Status and Apartment Price, Journal of Real Estate Research, 12(1), 101-109.

Mitnick, B.M. (1992) The Theory of Agency and Organizational Analysis in Bowie, N.E. \& Freeman, R.E. (ed.), Ethics and Agency Theory, Oxford University Press, New York, 7596.

Ong, S. E., Neo, P.H. andSpieler, A. C. (2006) Price Premium and Foreclosure Risk, Real Estate Economics, 34 (2), 211-242

Ong, S. E., Neo, P.H. and Tu, Y. (2008) Foreclosure Sales: The Effects of Price Expectations, Volatility and Equity Losses, Journal of Real Estate Finance and Economics, 36 (3), 265-287

Pennington-Cross, A. (2006), The Value of Foreclosed Property, J ournal of Real Estate Research , 28 (2), 193-214.

Shilling, J.D., Benjamin, J.D., \& Sirmans, C.F. (1990) Estimating New Realizable Value for Distressed Real Estate, The J ournal of Real Estate Research, 5(1), 129-140.

White, H. (1980) A Heteroskedasticity-Consistent Covariance Matrix Estimator And a Direct Test For Heteroskedasticity, Econometrica, 48(4), 817-838. 